\title{
LIS EDUCATION IN THE DIGITAL ERA
}

\section{Jincy Joseph ${ }^{1}$}

\author{
Carmelite Provincial House, Ernakulam ${ }^{1}$ \\ jincycmc@gmail.com ${ }^{1}$
}

\author{
Aneesh $\mathrm{CA}^{2}$ \\ Nirmalgiri college,Kannur ${ }^{2}$ \\ $\underline{\text { aneeshaugusty@gmail.com }}^{2}$
}

\begin{abstract}
This paper presented the development of LIS education in India and influence of technology in LIS education. Information explosion due to the modern technology change the designation of librarian to information scientist who is capable for retrieve right information to right user at right time. The user community only that brings the professional sustainability of a librarian must recognize this change from a traditional librarian to information scientist. This occurs only through the good education in handling or managing the technology. So the curriculum of LIS education must be IT oriented but it is different from other IT professional.
\end{abstract}

Keywords: LIS Education, Technology, Cloud Computing, India, Library automation, Digital Era

\section{INTRODUCTION}

The technology brings greater change in our everyday life. The technology enhance retrieval of upto-date information through cloud computing, internet etc. using tab, smart phone etc within seconds. No one has to go to library for information collection. Elearning and distance education bring tremendous changes in the use of information sources. Through online information resources easily and within short time we can retrieve our relevant information with no cost apart the availability of net. In this situation future of library and information science education is very perceptive. The concurrency of LIS education is a demanding factor for sustainability of library professional. The influence of IT in education also reflects in LIS education. In order to develop our skills to face the need of E-user is one of the greatest challenge LIS education in India have many things to further do.

\section{Library Profession in India}

India is a developing country which promotes education in all aspects. We can see that from the early scenario India gives very important place in education and library, where the information collected in the form of written documents. The first library training program is started by WA Bordon and from then we can see a slow and steady growth in library science education. In 1913 another training program conducted for librarians of the town. But a systematic training program was initiated by Asa Don Dickenson at Punjab University now it in Pakistan. The Punjab Library primer is a manual for students of library science, which was created by Mr.Dickinson. In the same year ie on 1920, a librarian training program conducted at Bangalore initiated by the then Dewan of Mysore, M. Vishweswarayya. But a regular certificate course in library science started by MALA from 1929 and which is took up by Univesity of Madras in 1931. In 1935 Andra pradesh University also started a Certificate course but it was shortly abandoned.

The first postgraduate course in library science is started by S.R. Ranganathan in 1936. In 1942 Banaras Hindu University started postgraduate diploma course occupy second place for starting postgraduate diploma course and third place goes to the University of Bombay which started similar diploma course in 1943.

Sir Maurice Gwyer initiated to start postgraduate diploma in library science with the help of Ranganathan in Delhi University. In 1948 the University of Delhi instituted the first diploma degree course in library science. The program of Master of library science was introduced as a two year course with the first year leading to post graduate diploma in library science. First B.Lib. Sci. course started in 1957 at Aligarh Muslim University. ${ }^{\mathrm{i}}$

In between 1956-1959 six new LIS departments were established at Aligarh Muslim Universiy, MS University of Baroda, Nagpur university, Osmania Universiy, pune University and vikram University.In 1960 Madras university replaced full time diploma course to BlibSc degree course. By then many other universities follow madras university conducted library courses as per Review committee report of UGC. ${ }^{\text {ii }}$ DRTC and INSDOC startd 2 new specialized cources in 1962 and 1964 respectively. During the 1970s, the number increased to 42 .

Presently in India, Library and Information Science (LIS) education is imparted through more than 180 universities and institutions. A total of 131 universities provide Bachelor of Library and 
Volume 6 Issue 2 February 2018

Information Science (BLIS) courses, 136 universities provide the Master of Library and Information Science (MLIS) courses, among these 41 are offering two-year integrated courses, 21 universities provide M.Phil in Library and Information Science, 46 universities provide Ph.D in Library and Information Science and 2 Universities provide D.Litt Degree. Besides this, the National Institute of Science Communication and Information Resources (NISCAIR) which was earlier known as the Indian National Scientific Documentation Centre (INSDOC), New Delhi, and Documentation Research and Training Centre (DRTC), Bangalore, provide Associateship courses in Information Science, which are equivalent to the MLIS degree. IGNOU started its BLIS in 1989 and MLIS in 1996 through distance mode right from late eighties and this move was followed by different dual mode state universities ${ }^{\mathrm{iii}}$

Besides these courses various advanced level short term training programmes are being offered as part of continuing education programme. These courses are run by the institutions/organizations where the infrastructures and other facilities are easily available such NISCAIR, New Delhi, SAARC DOC centres, Newdelhi, INFIIBNET, Ahemedbad, NASDOC, NewDelhi, DELNET, New Delhi, IIM Luknow, SENDOC, Hydrabad, and various library and information sciene associations like ILA, IASLIC and universities. $^{\text {iv }}$

\section{Information Technology and LIS education}

After the USA, UK and some European countries, India is one among to provide ICT oriented LIS education to the students. In late 1960s and early 1970 teaching of computer application commenced in Indian Library Science Departments. The courses run by the DRTC and INSDOC also included a paper Library automation. Now a day's information technology is a subject in library science education.

\subsection{Implementation of Information technology in libraries}

- Almost all libraries turned to Automated libraries and digital libraries

- Different Library software's are used by libraries to manage the library activity

- Easy retrieval of information can be possible through internet via Google and other search engines

- Databases are available for easy retrieval of information.
- E book, E-journals, Subject gateways are available for information retrieval

- Cloud computing, institutional repositories, online courses, open access journals etc. brings tremendous change in the use of information.

\subsection{Influence of Digital Era in LIS education.}

Today due to the influence of information technology library profession changed from its traditional librarian concept to many others. He is neither a custodian of books nor handling only information available in written document. This information age creates a heavy demand on librarians to continue traditional library services for some 'patrons', while creating new technology-based services for Digital Native 'customers'. Digital Fugitive and Digital Native customers are at opposite ends of the customer service spectrum, but both deserve excellent library services. ${ }^{\mathrm{v}}$ So LIS education provide a capacity to the educands to handle all type of documents which is digital and non digital to satisfy the user with different range.

Library professional must be acknowledged with the computer literacy, capable for master the web, creating blog and webpage along with traditional subjects like classification and cataloging of information and needs of the society. They are also capable for communicate through internet facility to users. They must be aware about the use of information technology to serve their users in a right way at right time. The electronic environment demands to the librarian a range of skills which include managerial skill, IT skill and technical skill. The librarian should know about search techniques, database development, quality of online database, choice of database that is available. So the LIS education is also revised their curriculum to efficient the library professional to face these circumstances.

\section{Need of ICT education in Indian Scenario}

Though India provides ICT education from eary1970, the curriculum of library science education is needed to restructuring. The study among a total of 50 LIS professionals and students from Kerala reveals that curriculum of post graduation courses are needed to revise and provide more practical classes to the LIS students. In the present situation all most all technologies are studied in a theory mode, there is a need to provide practical classes, only through that librarians are capable of handling digital information in the present world. ICT and information retrieval are 
ISSN-2347-9698

Volume 6 Issue 2 February 2018

taught as full paper in the syllabus in all the universities in India. While other important ICT components like digitization, Web Designing, ELearning, etc. are taken as a topic in a full paper in most of the universities in India. LIS curriculum is concerned more elective papers should be offered, practical and theory papers should be integrated across the curriculum, emphasis should be on enhancing the number of specialized papers like E-publishing/Web publishing, information architecture, the Digital age/cultures, working with information etc. ${ }^{\text {vi }}$

Table 1: Need of ICT in LIS education

\begin{tabular}{|c|c|c|}
\hline $\begin{array}{c}\text { Ideas about } \\
\text { curriculam revision }\end{array}$ & $\begin{array}{c}\text { no.of } \\
\text { respondents }\end{array}$ & $\begin{array}{c}\text { percentage } \\
\text { of } \\
\text { respondent } \\
\text { s }\end{array}$ \\
\hline $\begin{array}{c}\text { Revise Curriculum of } \\
\text { LIS Education }\end{array}$ & 35 & $70.00 \%$ \\
\hline $\begin{array}{c}\text { Provide More } \\
\text { Practical Class about } \\
\text { IT }\end{array}$ & 39 & $78.00 \%$ \\
\hline $\begin{array}{c}\text { Provide classes on } \\
\text { topic like } \\
\text { Digitization,Web } \\
\text { Design }\end{array}$ & 15 & $30.00 \%$ \\
\hline $\begin{array}{c}\text { Enhancng specialized } \\
\text { papers like E- } \\
\text { publishing, } \\
\text { Information } \\
\text { architecture, }\end{array}$ & 24 & \\
\hline \multicolumn{2}{|c|}{} \\
\hline
\end{tabular}

\section{Barriers for revising ICT topics in LIS}

\section{Education}

Respondents also pointed out that there is some barriers to implement or giving a good ICT education in Library Science education

Some barriers are follows

- Lack of infrastructural facilities

- Lack of trained teachers

- Lack of computers and ICT equipments

- Unwilling to implement ICT structure to the library

- Lack of money to attend the software management training program

- Lack of interest to study new horizons of digital implementation in library and provide better service to user
Table 2: Barriers for ICT education

\begin{tabular}{|c|c|c|}
\hline $\begin{array}{c}\text { Barriers for ICT } \\
\text { education }\end{array}$ & $\begin{array}{l}\text { no.of } \\
\text { respondents }\end{array}$ & $\begin{array}{c}\text { percentage } \\
\text { of } \\
\text { respondents }\end{array}$ \\
\hline $\begin{array}{c}\text { Lack of infrastructural } \\
\text { facilities }\end{array}$ & 44 & $88.00 \%$ \\
\hline Lack of trained teachers & 42 & $84.00 \%$ \\
\hline $\begin{array}{c}\text { Lack of computers and } \\
\text { ICT equipments }\end{array}$ & 38 & $76.00 \%$ \\
\hline $\begin{array}{l}\text { Unwilling to implement } \\
\text { ICT structure to the } \\
\text { library }\end{array}$ & 25 & $50.00 \%$ \\
\hline $\begin{array}{l}\text { Lack of money to } \\
\text { attend the software } \\
\text { management training } \\
\text { program }\end{array}$ & 19 & $38.00 \%$ \\
\hline $\begin{array}{l}\text { Lack of interest to } \\
\text { study new horizons of } \\
\text { digital implementation in } \\
\text { library and provide better } \\
\text { service to user }\end{array}$ & 24 & $48.00 \%$ \\
\hline
\end{tabular}

\section{New horizons of Library science} education

- Add technological related subjects in curricula Like Information management, online services, Database management, database accessioning, digital information preservation, software installation, how to manage, organize, retrieve digital information, search techniques etc..

- Provide classes about web application, security aspects in digital information, Web Designing, E-Learning, E-publishing/Web publishing, information architecture, the Digital age/cultures etc.

- The LIS departments should try to make practical oriented class. Emphasis on hands on practice is required to develop skill especially in Digital information handling. So practical and theory papers should be integrated across the curriculum and add more specialized papers to enhance the skills and knowledge of LIS professionals up-to-date with Digital growth.

- Develop career-long education program which will support ongoing growth of information professionals with graduate certificates in specialized LIS subjects like web management, Knowledge management, Software installation, database management 
etc, to meet the needs of professionals at different stages of their careers.

- To make knowledge professionals who are capable for providing information in digital mode with quality and quantity within short time.

\section{Conclusion}

This is the age some of them are following traditional library system and some are trained in ICT and some are born and bought up with digital development. So it is a great task of a librarian to attract all type users to the library and provide necessary help for them. The LIS School can play an important role to produce professional manpower for present and future needs of knowledge society. To build a capacity like an information scientist, facilitator, navigator a librarian must be up to date with present growth of IT. So LIS education must be changed to more IT oriented more practical and more technical which helps the educands to develop their skills for the better service of the community. Without good infrastructure facilities no LIS school can cultivate or develop abilities of library professionals in future. So LIS schools, Library associations and UGC have to take it as challenge to implement good infrastructure and trained staff for the betterment of LIS education.

\section{Reference}

i Bhagat,Pralhad and Shrawan.(2014). New Man International Journal of Multidisciplinary Studies, 1 (9) ${ }^{\mathrm{ii}}$ Dave,Jigar L..(2013). Library And Information Science In India. Indian Journal of Research, 2(12).

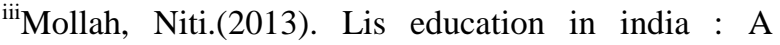
chorological and chronological study. e-library sciene Research Journal, 1(10)

${ }^{\text {iv }}$ Mahapatra, G. (2006). LIS education in India: Emerging paradigms, challenges and propositions in the digital era. Presented at the Asia-Pacific Conference on Library \& Information Education \& Practice 2006 (A-LIEP 2006), Singapore, 3-6 April 2006.

vhttps://21stcenturylibrary.com/2011/10/12/fivechallenges-every-librarian-must-face/

${ }^{\text {vi }}$ Siddiqui, S., \& Walia, P. K. (2013). A comparative analysis of Library and Information Science post graduate education in India and UK. 